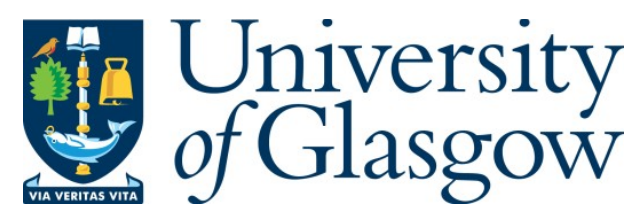

Werkmann, C., and Gherghina, S. (2016) Organized for parliament? Explaining the electoral success of radical right parties in post-communist Europe. Government and Opposition, (doi:10.1017/gov.2016.38).

There may be differences between this version and the published version. You are advised to consult the publisher's version if you wish to cite from it.

http://eprints.gla.ac.uk/133547/

Deposited on: 9 January 2017

Enlighten - Research publications by members of the University of Glasgow http://eprints.gla.ac.uk 


\title{
Organized for Parliament? \\ Explaining the Electoral Success of Radical Right Parties in Post-Communist Europe
}

\author{
Caroline Werkmann \\ Department of Political Science \\ Leiden University \\ Sergiu Gherghina \\ Department of Political Science \\ Goethe University Frankfurt \\ This is an Author's Original Manuscript of an article to be published in \\ Government \& Opposition.
}

\begin{abstract}
:
Over the last three decades a great deal of research has been carried out in an attempt to explain the electoral performance of radical right parties in Europe. Most approaches concentrate on demand side determinants and have some limitations. We compensated for these shortcomings and focus on the context of party competition and supply-side determinants (consistency of ideological discourse, functioning party propaganda, the continuity of leader in office, and strong party organization) to explain the electoral success of radical right parties in post-communist Europe. We conducted our analysis at party level on nine radical right parties in four countries from Central and Eastern Europe (Bulgaria, the Czech Republic, Hungary, and Romania) between 1990 and 2014. The bivariate and multivariate (ordinal logistic regression) analyses draw on unique data collected from primary and secondary sources.
\end{abstract}

Keywords: radical right, supply-side determinants, electoral success, party organization, post-communism

\section{Introduction}

The electoral success of several radical right parties in the 2014 European Parliament elections indicates the importance of these parties for current political systems. The search for an explanation of why radical right parties appealed to the public and managed to gain so many votes has produced and extensive body of literature. Most of this literature focuses mainly on demand-side causes of electoral success. Researchers have attempted to connect voting behavior with, on the one hand, macro-level developments such as modernization, economic and political crises, or the impact of migration (Beichelt and Minkenberg 2002; Betz 1993; Ignazi 1992; Lubbers et al. 2002; Rydgren 2007; Thieme 2007) or, on the other hand, with micro-level issues such as the expression of anti-establishment protest or of ideological support (Fennema 1997; Ivarsflaten 2008; Van der Brug et al. 2000). Critics of this perspective point out that demand-side explanations fail to acknowledge the crucial role of party agency in maintaining electoral support (Mudde 2011). If there is a certain political and 
societal 'climate' which benefits the radical right, why do some parties perform better than others?

Building on this critical approach, we emphasize the relevance of supply-side factors in explaining the variation in electoral success of radical right parties in post-communist Europe. We thereby provide a necessary complement to existing demand-side approaches. To this end, we propose and test the explanatory power of a favorable electoral opportunity structure, the consistency of ideological discourse, functioning party propaganda, the continuity of leader in office, and strong party organization. The analysis was conducted between 1990 and 2014 at party level on nine radical right parties in four Central and Eastern European countries (Bulgaria, the Czech Republic, Hungary, and Romania). Our comparative approach using an intermediate number of cases also helps close a gap. This gap has developed because the existing research contains few studies of intermediate numbers. It consists mostly of either single-case studies or comparisons of large numbers of cases. Studies of intermediate numbers are required, and are necessary, because single-case studies allow only limited generalization of the findings and studies of large numbers lack the extensive analysis of complex causal mechanisms and processes which medium- $\mathrm{N}$ studies provide. Our study combined qualitative content analysis requiring the collection of primary data from party documents (manifestos and statutes) with desk research for collecting secondary data from databases, party histories, and existing studies. The analysis used both bivariate and multivariate statistics to identify patterns and explain causal relationships.

The first section of the paper briefly presents our concept of radical right parties, the unit of observation in this article. The second section includes the theoretical and analytical framework of our study. It briefly presents the supply-side theories used to explain the success of radical right parties in Europe and formulates testable hypotheses. The third section describes the research design with particular attention to case selection, variable operationalization, and methodology used. Thereafter, we present the empirical tests of the relationships hypothesized and present the bivariate and multivariate analyses. In the conclusions we summarize the main findings, discuss the main implications of this analysis for the study of radical right parties, and suggest directions for further research. 


\section{What counts as Radical Right in Post-Communist Europe?}

There is no commonly accepted definition of the term "Radical Right" despite the increasing number of studies on radical right parties. Scholars do not even agree on the term to use for this group of parties, let alone on the core ideological features such parties share. The wide range of terms is reflected in the titles of research publications about the radical right (Betz 1993; Carter 2005; Ignazi 2003; Merkl and Weinberg 2003; Mudde 2007; Norris 2005; Van der Brug et al. 2000). Discussion of the different concepts represented by these terms goes beyond the goal of our analysis. It is nevertheless essential to clarify what we mean by "radical right parties" in general and also in the specific context of post-communist Europe. We have to determine how radical right parties differ from other political actors. Our starting point for this process is the general scholarly consensus that "Radical Right" refers to a specific type of ideology (Carter 2005: 14). Earlier studies have revealed that radical right actors differ both from mainstream actors and from extremist or other actors situated at the periphery of the political spectrum (e.g. populists). Common conclusions are that radical right parties are characterized by their rejection of liberal democracy, and express their rejection in an anti-pluralist, anti-minority rights and anti-parliamentary ideology. Radical right parties differ, however, from extreme right, i.e. anti-democratic, parties because they accept the concept of democracy and use democratic means of political participation, e.g. contesting elections (Mudde 2000; 2014; Ignazi 2003; Norris 2005; Rydgren 2007).

In addition to these features, most scholars agree that nativism as a specific form of nationalism has to be included in the core ideology of a party if it is to be considered radical right (Betz 2003: 78-79; Liang 2007: 7; Mudde 2007: 19). Thus, radical right parties strive to create a unitary nation-state in the nativist sense that the state "should be inhabited exclusively by members of the native group ('the nation') and that non-native elements (persons and ideas) are fundamentally threatening to the homogenous nation-state" (Mudde 2007: 19). Authoritarianism is considered another feature of the radical right core ideology (Heinisch 2003: 95; Karácsony and Róna 2011: 63; Liang 2007: 4; Mudde 2007: 22). All parties of the radical right in this study emphasize in their program a law and order doctrine aimed at threats from outside the nation, e.g. mass immigration, and against internal political enemies (Heinisch 2003: 95). Moreover, parties of the radical right are sceptical of the European Union (EU). They oppose the shift of power from the national to 
the supranational level and seek to re-strengthen national sovereignty. However, it is rare for them to clearly reject a country's EU membership.

Furthermore, there are additional features that distinguish the radical right parties in post-communist Europe from other similar parties outside this region. One is a strong statist position on economic issues, expressed in condemnation of privatization and calls for renationalizing recently privatized industries (Ghodsee 2008: 36). The pro-state position of radical right parties is also protectionist, that their own nation should be put first, e.g. to "buy Hungarian", and can therefore be labeled economic nationalism (Bíró-Nagy and Róna 2013: 8-9). Furthermore, radical right parties in post-communist Europe share a clear antiestablishment attitude. They present themselves as opponents to the political elite which they usually portray as corrupt and not representative of the will of the people (Eatwell 2004: 12; Rydgren 2005: 427). Outside the post-communist region these are features of populism. Mudde (2007: 23) claims that such an ideology "considers society to be ultimately separated into two homogeneous and antagonistic groups, 'the pure people' versus 'the corrupt elite', and which argues that politics should be an expression of the volonté générale of the people".

In the light of these features, we define as radical right those political parties from post-communist Europe that fulfill more or less the following criteria: they reject liberal democracy (have an anti-parliamentary ideology), use an anti-pluralist and anti-minority rights rhetoric, strive for a nation-state in the nativist tradition, promote a law and order doctrine aimed against external threats to the nation (including skepticism of European Union), favor a statist position on economic issues, and display an anti-establishment attitude. After this brief conceptualization of radical right, the following section reviews the existing determinants and formulates some empirically testable hypotheses.

\section{The Electoral Success of Radical Right Parties: Supply-Side Explanations}

Theories on the electoral performance of radical right parties both in Western and Eastern Europe can be broadly categorized as demand-side or supply-side approaches (Eatwell 2003; Norris 2005; Mudde 2007). Demand-side approaches assume that there is a certain environment that fosters the success of radical right parties, i.e. which form a "perfect breeding ground" (Mudde 2007: 202). Demand-side theories focus predominantly on macrolevel developments such as modernization (modernization losers' thesis), economic and 
political crises (post-materialism), and the impact of immigration (ethnic threat) (Lubbers et al. 2002; Eatwell 2003). Supplementary, micro-level explanations include the debate about whether voting for the radical right is an expression of protest against the establishment or of support for radical right ideology (Mudde 2007: 226). An extensive body of research indicated a large array of problems in using demand-side explanations alone for predicting the electoral success of radical right parties Van der Brug et al. 2000; Eatwell 2003; Norris 2005; Mudde 2007; 2014). To this end, some authors have tried to complement demand-side explanation with supply-side approaches in an attempt to provide an exhaustive explanation for differences in electoral success (Van der Brug et al. 2005).

We follow the argument that supply-side determinants can enrich the picture and provide useful insights into what determines the electoral fate of these parties. This perspective gains increased relevance in the context of recent work that illustrated how political parties in general, not just those of the radical right, from Central and Eastern Europe can augment or stabilize their electoral support through their own organization (Tavits 2013; Gherghina 2014). Following this logic, we emphasize the importance of supplyside theories in explaining the electoral success of radical right parties. In the following section we derive five empirically testable hypotheses.

The supply-side perspective focuses on characteristics inherent in the radical right parties themselves and in the competitive political structure in which they operate (Van der Brug et al. 2005: 539). They can be categorized into those concentrating on external, and those concentrating on internal factors (ideology, leadership, and organization) (Mudde 2007). External factors are the subject of the political opportunities approach (Tarrow 1998). This approach covers a variety of arguments about the institutional, cultural, and political context (Rydgren 2007). The institutional and cultural factors are not sufficient to explain party-level variation within the same country. For example, all political parties running in elections follow the same game rules and thus the electoral system cannot explain why two radical right parties have different electoral performance. Similarly, cultural arguments suggest that in countries where the nativist discourse is relatively widespread among mainstream parties, radical right parties are better able to legitimate their radical antiimmigrant rhetoric (Eatwell 2003: 59). While this can explain differences between countries, they cannot explain differences between the electoral success of radical right parties active in the intellectual environment of the same nation. 
The only variable belonging to the external supply-side category that may explain party-level variation is the electoral opportunity structure. Earlier research showed that this explains the variation in electoral results of radical right parties in Western Europe (Norris 2005; van der Brug et al. 2005; Meguid 2008; Arzheimer 2009). They showed how the programmatic strategies of competitors appear to be essential for the electoral success of radical right parties. By competitors earlier studies referred mainly to mainstream political parties that were competing with radical right parties on their core themes (Arzheimer and Carter 2006), on the economic dimension (Kitschelt 1995; de Lange 2007), or on both (Spies and Franzmann 2011). In brief, radical right are less successful at the polls when their message is covered by other competitors. In the West European context these competitors were the mainstream parties from the right side of the political spectrum.

These theoretical considerations have limited applicability in post-communist Europe where evidence goes in two directions. First, there are national settings in which more than one competitor covers some programmatic issues of the radical right parties. For example, in Romania throughout the 1990s various political parties spread along the left-right axis had an important emphasis on the national dimension and the necessity for the rule of law. These parties ranged from the radical left Socialist Workers' Party and left-wing Party of Social Democracy in Romania to the conservative Christian Democratic National Peasants' Party. These two topics were quite appealing to the public and thus more parties approached them without influencing the electoral success of the radical right. While the topic coverage by other competitors was a constant, the fortunes of radical right parties fluctuated. Second, in other national setting there are only isolated cases in which other political parties cover the discourse of the radical right parties. For example, in Hungary until the 2010 elections the position of the radical right was not contested in a substantial manner by mainstream political parties; in Bulgaria it was a similar situation until the 2009 elections. In the Czech Republic the radical right was challenged only to a limited degree in its euroscepic component by the Civic Democratic Party among the political parties with a constant presence on the political scene. These examples show that the competition of the radical right with the mainstream parties cannot explain the electoral fortunes of the latter; the main reason is the absence of variation.

Instead, what varies is the competition between radical right parties. Rydgren (2007: 257) points out that little research has been done on the competition between different 
radical right parties within one country. He expects that the opportunity for a radical right party to enlarge its support decreases when several radical right parties compete against each other in elections. Under these circumstances, votes are likely to be split between the competing parties so that none is able to gain a significant share. In line with this argument, we argue that the electoral opportunity structure is favorable for radical right parties when they face no competition from other radical right parties. An increase of votes for one radical right party will occur at the expense of the others. Accordingly, we hypothesize that:

H1: Radical right parties facing a favorable electoral opportunity structure are likely to be successful in elections

At this stage, we must make two important clarifications. First, the existence of wellorganized minority parties in the party system may be important for the electoral success of radical right parties. This can happen especially because the formation of some radical right parties (e.g. in Romania) can be seen as a response to the political organization of an ethnic minority (Millard 2004). From an empirical point of view, there is no longitudinal variation: once formed, ethnic minority parties continued to exist while support for the radical right oscillated widely (e.g. in Bulgaria and Romania). Second, earlier studies pointed in the direction of theoretical reasons to expect that competition from mainstream parties would inhibit the electoral success of radical right parties (Norris 2005; Meguid 2008). When mainstream parties approach issues that are at the core of radical right discourse (e.g. crime, nationalism), the radical right lose their "selling points" and are thus unlikely to perform well in electoral competition. However, there are empirical reasons why we do not use this approach. Data from the Comparative Manifesto Project indicates that there are only isolated instances in which the mainstream political parties compete on some dimensions against the radical right in the investigated countries. Nevertheless, in general the radical right parties stem out as distinctive actors in their discourse. For example, the 2013 Bulgarian elections marked the moment when Ataka had competition on the law and order dimension on which it was quite far from mainstream political parties since 2005 . The Citizens for European Development of Bulgaria (GERB) emphasized this dimension to a similar extent with Ataka. However, since their discourse differed fundamentally on many other dimensions (minorities, position towards the EU), their general left-right positioning is 
very different. The same holds true for another example where one may expect more resemblances: in spite of their similarities on some discourse dimensions Jobbik and Fidesz are quite different in their appeals and the final left=right positioning of the two is very different in the 2014 elections.

The favorable political opportunity explanation fails to take party agency into consideration and this is one reason why we complement it with determinants belonging to the supply-side category. These are internal features such as ideology, propaganda, party leadership, and party organization. In terms of ideology, there is a general consensus that there is little chance for extreme right parties with an overtly anti-democratic and fascist ideology to be electorally successful in contemporary Europe (Carter 2005; Mudde 2007; Rydgren 2005). Therefore, the capability to "ward off an extremist image" increases the credibility of the radical right (Van Kessel 2011: 27). Rydgren (2005: 416) states that the radical right has developed a new "master frame" that includes cultural instead of biological racism as well as an anti-establishment instead of an anti-democratic discourse. Cultural racism, or ethno-pluralism, declares that ethnicities are disparate and not compatible with each other and should therefore not be mixed (Betz 2003: 73). The combination of cultural racist and anti-establishment views appeals to voters who would never cast a vote for a party that was openly anti-democratic and racist (Rydgren 2005: 416).

Betz (1993: 413), however, claims that libertarian values such as the free market or a limited role of the state, are part of the radical right "winning formula". However, his study covers only western European countries. As mentioned above, party development in postcommunist Europe differed greatly from its development in Western Europe. Hence, in contrast to Betz's perception, the radical right in post-communist Europe takes a clear prostate standpoint. As this example shows, different scholars suggest different aspects making up the perfect ideological recipe (Mudde 2007: 257).

Instead of defining such a master frame for explaining the electoral success of radical right parties, we emphasize the role of their ideological consistency. Ideological consistency is the degree to which a party's program remains the same through the years. Sending a homogenous message to the electorate improves the party's stability and consequently leads to the stabilization of electoral preferences (Gherghina 2014). The electorate sees coherence of the party program as the outcome of strong internal party discipline (Carter 2005: 65). The credibility of a party improves if there is a high level of consistency in the 
party's discourse and leads to greater electoral support. Therefore, we expect consistency in discourse to improve electoral performance:

H2: Radical right parties with a consistent ideological discourse are likely to be successful in elections

The extent to which a radical right party is able to make its ideology publicly available through party propaganda is also crucial to building up a "'cultural hegemony' of political and social discourse in order to shape a particular social and political reality" (Liang 2007: 28). While the mainstream media are used as a platform for electoral breakthrough, party propaganda plays an important role in maintaining electoral support (Mudde 2007: 260). Party websites, internet forums, and chats enable smaller parties to reach the public even when their message is not transmitted through mainstream media channels: "The Internet has allowed the populist radical right an equal speaking platform with established mainstream parties" (Liang 2007: 6). Radical right parties increasingly build up wellstructured websites, some even with English translations to act as a role model for others in the party family (Eatwell 2004: 2-3). Well-presented party websites, multi-media offerings, and constantly updated web-blogs all aim at creating the above mentioned cultural hegemony (Liang 2007: 28). Following these arguments, we hypothesize that:

H3: Radical right parties with extensive propaganda means are likely to be successful in elections

Party leadership is also a relevant determinant of electoral success especially when charisma is involved. Studies have pointed out that radical right parties are likely to be successful at the polls when the leader is perceived as charismatic. Eatwell (2005: 116) distinguishes between coterie charisma that attracts supporters "who have held that the leader was driven by a special mission and/or that the leader was invested with unique powers" and centripetal charisma where leaders "are not necessarily viewed as the embodiment of a special mission, but more as the embodiment of the party". Such leaders are able to attract voters by presenting themselves as the personification of party policies. Brichta and Pedahzur (2002) argue that leaders need different skills in the different phases of party development and institutionalization. Charisma and alluring communication skills are especially important in the first phase, i.e. party identification. This would relate to the 
category of external leadership. In the second phase, i.e. party organization, the leader has to engage in building up party structure. The third phase, i.e. party stabilization to strengthen party organization and maintain electoral support, requires a "moderator and stabilizer" who is perceived as reliable and credible. Along these lines, Mudde (2007: 261262) suggests that external leadership is important for electoral breakthrough, whereas internal leadership is important for strengthening party organization during the phase of preserving electoral stability. Leadership therefore does matter in explaining electoral success since it plays a crucial part in building up a strong party organization.

A leader able to provide the skills needed in the different phases of institutionalization is expected to be re-confirmed and re-elected in office. Radical right parties are likely to be more stable when change in leadership does not occur too often because leadership continuity ensures homogeneity of the party organization (Gherghina 2014). This is also the case for mainstream parties but the impact is likely to be greater for radical right parties since their leaders are the "face of the party", and sometimes are literally so on party websites (Ghodsee 2008: 32). They often embody the politics of the party, both by party members and the electorate. Following Carter (2005: 65), electoral support is expected to decline when the leader, as the defining figure of the party, leaves office, whether they leave because of age, of an internal dispute, or because they join another party. Therefore, we hypothesize that:

H4: Radical right parties with continuity of leader in office are likely to be successful in elections

Closely related to leadership, party organization is likely to play a relevant role in explaining the electoral success of radical right parties. Earlier studies revealed that well-organized radical right parties are more successful at the polls than those that are poorly organized (Carter 2005: 65; Lubbers et al. 2002: 371; Norris 2005: 263). The availability of party resources, including human and financial resources, is essential if a party is to strengthen its organization. Lubbers et al. (2002: 351) stress the importance of party activists on the local and regional level in order to organize strong campaigns. Party youth organizations are a source of personnel since they strongly engage in recruiting young people both as future voters and as party members (Mudde 2007: 269). Recruitment of competent personnel is especially important after electoral breakthrough in order to prevent radical right parties 
becoming "the victim of their own success" when they have to fill up positions in the party structure (Mudde 2007: 266).

Financial resources also matter for effective campaigning (Norris 2005: 263). A strong grassroots base and local or regional strongholds help to maintain electoral support and serve as a source of recovery after weak electoral performance or party factionalism (Mudde 2007: 269-270). There is also a role for internal party discipline. This can only be enforced through institutionalized party rules and centralized, often highly centralized, structures (Carter 2005: 65; Norris 2005: 263). In general, the degree of organizational development is an important aspect to party success. Parties with a strong organization are better able than those with weak organization, to survive internal conflicts and factionalism (Carter 2005: 80). Following these arguments, we expect effective party organizations to have an impact on their electoral fortunes:

\section{H5: Well-organized radical right parties are likely to be successful in elections}

Some theoretical arguments point in the direction of reverse causality. In many post-communist countries the public funding of political parties largely depends on their electoral success. Political parties gaining legislative seats receive considerably more funding than the extra-parliamentary ones; the funding for parliamentary parties is distributed according to their share of seats. Moreover, political parties also rely on private funding and usually sponsors choose the important parties with influence on policy. All these indicate that electoral success may shape parties' organizational strength and propaganda means and further lead to electoral success. However, the political reality of the analyzed countries is somewhat different and leaves little room for such concerns. On the one hand, there are variations in the electoral success of the radical right parties in consecutive elections. Under these circumstances, the theoretical argument regarding the spiral of success (electoral success fosters further electoral success) does not hold in practice. On the other hand, there is no clear pattern regarding the development of organizations and media channels following an electoral success. After gaining parliamentary seats some political parties lost some of their organizational strength and did not increase the number of used media channels. The statistical analysis confirms the limited likelihood of reverse causality. For example, the correlation between strength of party organization - measured until the moment of elections $t_{0}$ - and elections at moment $t_{0}$ is 0.40 , statistically significant at the 0.01 level (Table 1). The correlation between electoral success at moment $t_{0}$ and strength of party organization, measured as a consequence of this electoral success 
between $t_{0}$ and $t_{1}$, is 0.29 (not statistically significant). Similarly, the results of an ordinal logistic regression with strength of organization as dependent variable and electoral success and propaganda channels as independent variables indicate that electoral success is considerably weaker $(O R=1.67$, not statistically significant) compared to propaganda channels $(O R=3.65$, statistical significance at the 0.01 level). The variation in the strength of the organization is thus better explained by factors that develop between elections rather than by an election in the past.

\section{Research Design}

This article aims to explain the electoral success of radical right parties in four postcommunist countries: Bulgaria, the Czech Republic, Hungary, and Romania. These countries were selected because they previously had communist regimes and were members of the Warsaw Pact but not of the Soviet Union, experienced a multidimensional transformation process (economic, political, and societal), transition challenges, and all became EU members within the same short period (2004 and 2007). These shared features reduce the effect of inter-country differences and thus allow us to focus on the features that differ at the level of observation (Landman 2008; Norris 2005).

The analysis was conducted at party-level and the unit of observation was the radical right party or an election. We studied both national and European elections and examined a period of 25 years between the first free and fair elections after change of regime in Hungary (March 1990) and the most recent European Parliamentary elections in May 2014. The study included seven national elections in Hungary and Romania, eight national elections in Bulgaria and the Czech Republic ${ }^{1}$, and three in each country. Hungary and the Czech Republic took part in the 2004 European Parliamentary elections and Bulgaria and Romania, due to their accession in 2007, held elections in 2007. All four countries organized elections in 2009 and 2014 and the total number of items observed was 45. Our analysis included those parties that fulfilled both of the following criteria: 1) they share the ideological features of the radical right (see the conceptual section) and 2) they have contested at least one national or European Parliamentary election without being allied to another party. This criterion was used to exclude political parties with operating exclusively locally and those parties competing only in alliances or coalitions. In alliances and coalitions the distribution of power often remains unclear because there is no transparency about the number of seats

\footnotetext{
${ }^{1}$ The Czech election results of 1990 and 1992 represent the outcome of the elections to the Czech National Council of the Federation of Czechoslovakia.
} 
assigned to each component of the alliance (Gherghina 2014). A total of nine parties met these two criteria: the Attack Party (Ataka) in Bulgaria; the Association for Republic Republican Party of Czechoslovakia (SPR-RSČ) and its successor, the Republicans of Miroslav Sládek (RMS), the Workers' Party (DS) and its successor, the Workers' Party of Justice (DSSS), in the Czech Republic; Jobbik, Movement for a Better Hungary (Jobbik), and the Hungarian Justice and Life Party (MIÉP) in Hungary; the Greater Romania Party (PRM) and the Party for Romanian National Unity (PUNR) in Romania. We use ordinal regression ${ }^{2}$ with robust clustered errors to compensate for the violation of independence of observations. The cases may be clustered on nine political parties although the variation of the independent variables shows little reasons for concern. For example, a consistent ideological discourse $(\mathrm{H} 2)$ before election $t_{1}$ is not related to the continuity of the same discourse in the previous election to. At the same time, the number of propaganda channels oscillates from election to election and political parties do not necessarily maintain some channels and add new ones but, instead, they remove some and change others.

To classify the parties as radical right and to measure the five determinants, we combined the qualitative content analysis of party websites and manifestos with desk research that systematically analyzed the party histories, electoral data, and lists of candidates. When secondary data was only partly available (e.g. for the ideological positioning of political parties), for reasons of consistency, reliability, and comparability we collected primary data for all the cases investigated. The result was a unique dataset including data collected from primary and secondary sources.

\section{Variable operationalization}

The dependent variable, the electoral success of radical right parties, was measured relative to the electoral threshold necessary to gain seats in the national parliament (the lower chamber for bicameral systems) or in the European Parliament. We operationalized the variable on a three-point ordinal scale where 0 corresponds to lack of electoral success (i.e. the party did not gain access to parliament), 1 is equivalent to minimal success (i.e. the party scarcely managed to pass the electoral threshold) and 2 for a comfortable success (i.e. the party achieved a vote share at least 1.5 times the threshold). This measure is used to capture

\footnotetext{
${ }^{2}$ The cutoff points used in the dependent variable do not influence the results of analysis. We used different values for category 2 and the results changed only marginally.
} 
the degree of electoral success relative to the electoral threshold and to allow for comparability of results across political parties. Being present in parliament is crucial for many political parties because it ensures greater visibility and opportunities to shape policies. The values of thresholds differed between the countries investigated, within some countries for single parties and alliances, and over time. In the light of these differences, the percentage of votes gained in an election does not reflect the degree of electoral success. If one radical party gets $4.5 \%$ in the context of an electoral threshold of $4 \%$, from our point of view is more successful than a radical right party that gets $4.9 \%$ in an election with $5 \%$ threshold (being in parliament vs. not gaining seats). At the same time, it is relevant to distinguish between political parties that are on the edge and those that are successful. A dichotomous measure would have differentiated between failed and successful attempts to gain seats but would not have fully reflected the degree of success. At the same time, this combination of share of votes and share of seats is useful when the electoral system has a proportional representation component that ensures a connection between the two. If national and European elections were held in the same year, we considered them part of the same electoral cycle. Thus, the length of the electoral cycle could vary from one year to four years.

The electoral opportunity structure $(\mathrm{H} 1)$ was defined as favorable for radical right parties if they faced no competition from other radical right parties within the same party system. This produces a dichotomous variable where 1 corresponds to situations when no other radical right party competes in the same election (favorable electoral opportunity structure) and 0 corresponds to situations where there is competition between two or more radical right parties (no favorable electoral opportunity structure). Consistency of ideology (H2) was characterized by the coherence of the party discourses compared to previous positions. To measure the ideological consistency, we focused on four key issues in the ideological and political programs and party manifestos; 1 ) position on minority rights; 2) position on law and order; 3) position on the state's role in the economy and 4) position on the role of the EU. We compared the party positions during an electoral cycle with those expressed in the previous election. Each of the four issues was coded separately as a dummy variable ( 0 for change in position and 1 for consistency) and scores were aggregated in a cumulative five-point index that ranged from 0 (no consistency in any of the four dimensions) to 4 (consistency in all four dimensions). The continuity in ideological discourse 
was assessed on the basis of a systematic analysis of the party manifestos by comparing and contrasting their positions on the four issues in subsequent elections.

Party propaganda $(\mathrm{H} 3)$ is the extent to which a radical right party is able to make its ideology publicly available to the electorate. The effectiveness of party propaganda increases when the party uses a variety of channels outside of the mainstream media to spread its message, e.g. own newspaper, TV channel, and a party website. These three indicators cover different types of platforms and multi-media channels and each of them was coded dichotomously to reflect presence (1) or absence (0). For example, a party received a score of 0 if it had no website or an outdated website (one that had not been updated for more than one year at the time of an election) and 1 if it provided an updated informative website. A website was considered updated and informative when important documents such as election programs were easily identified and when it kept the website visitor fully up to date about party actions by website articles, videos or by other means. The score for party propaganda was a four-point cumulative index that ranged from 0 (no media channel for propaganda) to 3 (all three channels for propaganda).

Continuity of leader in office $(\mathrm{H} 4)$ was measured relative to the previous electoral cycle. Continuity exists when the leader at the time of the previous electoral cycle is still in office, or has been re-elected to office. This variable is coded dichotomously with a score of 0 corresponding to leadership change and 1 to leadership continuity.

The strength of party organization (H5) is operationalized by two indicators: 1) the degree of party nationalization, i.e. the territorial coverage of local branches and 2) fielding candidates. The vote shares of parties with wide national coverage do not differ much from one geographic unit to the other. Those with little coverage goes along with widely varying vote shares across territorial units (Jones and Mainwaring 2003). This indicator was measured on an ordinal scale with 0 corresponding to little coverage (the party organization was represented only in the capital city), 1 means that the party branches covered up to half of the country, and 2 if the local party branches covered more than the half of the country. The second indicator refers to a party's ability to present a full list of candidates in elections. Having enough candidates for a full list demonstrates a strong party organization since it implies that the party has been able to ensure sufficient human resources (Kopecký 2006). This indicator was also coded on a three-point ordinal scale where 0 indicated having a list of candidates equal or fewer than half the number of seats in parliament, 1 when the party 
fields up to $2 / 3$ the number of parliamentary seats, and 2 if the party fields a full list of candidates. The score for organizational strength is a cumulative index that ranges from 0 to 4 for its organization, with 0 being very weakly-organized and 4 being very well-organized. When computing the indices indicators were given equal weight.

\section{Analysis and Results}

Electoral success greatly differed between the political parties investigated. In $11 \%$ of cases, radical right parties gained access to parliament with a vote share only slightly above the electoral threshold. Parties achieving comfortable electoral success made up $34 \%$ of cases and in $45 \%$ of cases radical right parties were electorally successful, i.e. gained access to parliament. In $55 \%$ of cases, therefore, radical right parties were unsuccessful in parliamentary elections. The Bulgarian Ataka and the Hungarian Jobbik were the two most successful parties in this study. Ataka was comfortably elected to parliament in five out of the six elections they contested, while Jobbik had large success in four of the five elections it took part in. Among the least successful parties were the DS and the DSSS in the Czech Republic neither of which ever gained access to parliament and the Hungarian MIÉP with minimal success in 1998 alone but failing to pass the threshold in seven other elections. The electoral result of several parties varies over time. For example, the PRM was represented in the Romanian Parliament in 1992-2008 and in the European Parliament in 2009 but gained no seats in the 2008 and 2012 national or in the 2007 and 2014 European elections.

Table 1 presents the variation of the independent variables included in our analysis. The distribution of the 45 units of observation (party/election) reveals a nuanced picture. For example, while an extensive body of literature speaks about the importance of charismatic and long lasting leaders in the life of radical right parties (confirmed by the continuity dimension), many of the parties under investigation developed strong or very strong organizations (score 3 or 4 on the index) in parallel. The radical right parties analyzed in this study generally showed a great degree of consistency in their ideological discourse. We observed cross-party similarities in terms of linking law and order programs with antiminority sentiments. For example, Ataka's Program Scheme of 2007 and Jobbik's 2010 manifesto show great similarities in their ideological discourse. Ataka calls for the reintroduction of the death sentence and wants to set up a program to reduce and eradicate "gypsy criminality". Likewise Jobbik claims that the police force should be strengthened to 
stop "gypsy crime". Only one case, the PRM in 2004, showed inconsistency in ideological discourse, i.e. change in two out of four dimensions. Since its creation, the PRM discourse has been characterized by strongly anti-Semitic sentiment and its leader Vadim Tudor is known for his hate speeches against Jews and for denying the Holocaust. Moreover, the party has long rejected the country's accession to international organizations. In 2004, however, the PRM radically changed its ideological discourse on these dimensions. Tudor apologized in an open letter for its anti-Semitic statements and declared PRM support for Romania's accession to a "united Europe". Because of this ideological change and electoral performance this case strongly contradicts the relationship hypothesized. Had this case been left out, the relationship would have been even stronger than it appears in the analysis.

Table 1: The Distribution of Radical Right Parties on all Independent Variables (\%)

\begin{tabular}{lccc}
\hline & Favorable & Not favorable & \\
Electoral opportunity structure & 58 & 42 & \\
\hline Ideological discourse & Fully consistent & Quite consistent & Inconsistent \\
\hline & 87 & 11 & 2 \\
\hline Propaganda channels & One channel or less & Two channels & Three channels \\
\hline & 36 & 40 & 24 \\
\hline Leadership continuity & Continuity & Change & \\
\hline & 76 & 24 & \\
Strength of party organization & Weak or medium & Strong & Very strong \\
\hline
\end{tabular}

It is quite relevant to note that the majority of these parties also developed extensive propaganda channels (two or three). Ataka and Jobbik were the parties using the three media channels most extensively. Ataka publishes a daily newspaper Vestnik Ataka and maintains a very informative website which is continuously updated about the party's actions. The party chairman, Siderov hosts the TV show Ataka and the party launched its own TV channel Alfa TV in October 2011. Similarly, Jobbik has frequently updated website, distributes a weekly newspaper Barikád and has four YouTube channels, frequently updated, where videos of Jobbik parliamentarians, gatherings or other important events are constantly uploaded. Some radical right parties increased the number of propaganda channels used. Using the same example of Jobbik, the party started with a website in 2006 but introduced a newspaper and build up an extensively updated multi-media platform between 2006 and 2009. Others used a fluctuating number of media channels. For example, the SPR-RSČ had the support of the weekly party newspaper Republika from 1990 to 2004 
and maintained an informative updated website between 2002 and 2009. Thus, in the 2002 and 2004 elections, the party used two channels for its propaganda but none 2010 (i.e. neither published a newspaper nor kept its website updated).

Two empirical remarks should be made before proceeding further. First, the time factor does not hold explanatory power when it comes to the electoral success of radical right parties. Although the use of propaganda channels is directly and strongly related to time (i.e. from 2002 onwards the number of cases with at least two functioning media channels is significantly higher than in the previous election years), time says almost nothing about electoral results since radical right parties are not more successful in the second postcommunist decade compared to the 1990s. Second, the length of an electoral cycle correlates weakly $\left(0.21\right.$, not significant $\left.{ }^{3}\right)$ with the electoral success of radical right parties. Whether an election was preceded by a short or a long interval appeared to make little difference to their success i.e. running in European elections.

Table 2 includes the results of the bivariate analyses between the electoral success and each independent variable. The correlation coefficient for the electoral opportunity structure (0.02, with no statistical significance) indicates no empirical support for the hypothesized relationship ( $\mathrm{H} 1)$. In the light of these results, competition between radical right parties does not alter their probability of gaining parliamentary seats. There is some empirical support for $\mathrm{H} 2$ in the form of a weak correlation between the consistency of ideological discourse and electoral success $(0.19$, no statistical significance). Its direction indicates that radical right parties with a consistent ideological discourse are more successful at elections than those that change their discourse. The findings are more valuable in the context of small variation on this dimension (Table 1 ).

Table 2: The Results of Bivariate Correlations

\begin{tabular}{lcc}
\hline Correlation between electoral success and... & Correlation coefficient & $\mathrm{N}$ \\
\hline Electoral opportunity structure & 0.02 & 44 \\
Ideological discourse & 0.19 & 44 \\
Propaganda channels & $0.31^{*}$ & 44 \\
Leadership continuity & 0.18 & 44 \\
Strength of party organization & $0.40^{*}$ & 39 \\
\hline
\end{tabular}

Notes: Reported coefficients are Spearman's rho.

* significant at $\mathrm{p}<0.01 ;{ }^{* *}$ significant at $\mathrm{p}<0.05$

\footnotetext{
${ }^{3}$ Statistical significance is not particularly relevant since observations are not a sample on the basis of which we can generalize but a complete universe of cases based on rigorous selection. Under these circumstances, statistical significance is useful to indicate that the relationship is not accidental.
} 
The moderate positive relationship between party propaganda and electoral success $(0.31$, significant at the 0.01 level) indicates that a large number of functioning media channels leads to an increase of electoral success. This brings empirical support for the hypothesis that parties using a variety of media channels for their propaganda are more likely to be successful than those without such means (H3). The coefficient for leadership continuity indicates weak support for $\mathrm{H} 4$ but in the hypothesized direction $(0.18$, no statistical significance). Accordingly, radical right parties with continuity in their leadership are more successful than those that change their leader. One exception was observed in Hungary where leadership change - Gábor Vona was elected as chairman of Jobbik after the 2006 parliamentary elections - had a positive effect on Jobbik's subsequent electoral performance. The relationship between the strength of party organization and electoral success ( $\mathrm{H} 5)$ is 0.40 , statistically significant at the 0.01 level, which indicates a moderate and robust correlation between the two variables. These findings support the relationship hypothesized that radical right parties with strong organization are more successful than poorly organized radical right parties. The bivariate analyses provide empirical support for all hypotheses related to the internal supply-side. Among these variables, party organization and number of propaganda channels appeared to be most important. At the same time, competition between radical right parties neither stimulates nor inhibits their electoral success.

The multivariate regression analysis puts all independent variables in a common model to estimate the likelihood of electoral success. The ordinal regression analysis (Table 3 , robust clustered standard errors in brackets) broadly confirms the findings of the bivariate analysis. ${ }^{4}$ The empirical evidence shows no support for the hypothesized relationship between favorable electoral opportunity structure and electoral success $(\mathrm{H} 1)$. On the contrary, the odds ratios indicate that radical right parties without competition from other radical right parties are 0.79 times less likely to be successful than those competing against parties of the same type.

\footnotetext{
${ }^{4}$ While no coefficient is statistically significant at the 0.01 or 0.05 level, this is of little interest to our analysis (see footnote 3). The lack of significance and the limited model fit (0.07) may have a methodological cause, i.e. the low number of observations. Consequently, our interpretation of the odds-ratios focuses on their size and direction to estimate the causal effect.
} 


\begin{tabular}{lc}
\hline & Odds ratios \\
\hline Electoral opportunity structure & $0.79(0.87)$ \\
Consistency of ideological discourse & $2.14(3.16)$ \\
Functioning party propaganda & $1.47(0.68)$ \\
Continuity of leader in office & $1.42(1.57)$ \\
Strength of party organization & $1.63(0.71)$ \\
\hline $\mathrm{N}$ & 40 \\
Pseudo $\mathrm{R}^{2}$ & 0.08 \\
Log pseudolikelihood & -35.79 \\
\hline
\end{tabular}

The findings of the ordinal regression provide empirical support for $\mathrm{H} 2-\mathrm{H} 5$. Radical right parties were twice more likely to achieve electoral success if they are consistent in ideological discourse than were parties without discourse consistency. In terms of propaganda, radical right parties with a large number of propaganda channels were 1.47 times more likely to be successful compared to those with no such channels. Radical right parties with leadership continuity were 1.42 times more likely to be successful than those where the leader was replaced, and radical right parties with strong organizations were 1.63 times more likely to be successful at the polls than those with weak organization.

\section{Conclusions}

This article aimed to explain the electoral success of radical right parties in four postcommunist countries between 1990 and 2014. To this end, it investigated the potential effect of five supply-side determinants and found that political parties with consistent ideological discourse, extensive party propaganda to make its ideology visible to the electorate, continuity of party leadership, and strong party organization had better electoral performance than the other radical right parties. At the same time, the electoral opportunity structure does not make a difference.

These findings have several implications that move beyond the examined cases. At the theoretical level, they shed light on the explanatory power of the supply-side explanations. This addresses the shortcoming of looking exclusively at the demand-side explanations and bring in the party agency. In particular, the internal supply-side components, i.e. party ideology, propaganda, leadership, and organization, have some explanatory power. Since these variables are not context or country sensitive, they can 
represent useful explanations in other settings and can be included in analytical frameworks. Since our case selection was based on the most similar system design, it is likely to find similar effects - in terms of direction and size - of supply-side determinants on electoral success in other new European democracies from Eastern Europe.

In terms of methodology, this study advances the debate on the operationalization of party organization by introducing the degree of nationalization and the ability to present a full list of candidates at elections as indicators for the strength of party organization. The quantitative operationalization of organizational components can be substituted for qualitative analysis models which are often not replicable. Consequently, the two indicators presented in this study may be helpful for future comparative investigations of party organization. The major empirical implication of this study is that radical right parties in postcommunist Europe are not a "one-man show" as often assumed in the literature. Although there is overall high continuity of leadership, the findings illustrate that political parties cannot be reduced to their leader. In contrast, the majority of radical right parties are also well organized and able to rely on effective propaganda machines to enhance their electoral success.

In spite of these contributions from our study, our exclusive focus on supply-side determinants prevented our analyzing the interplay between supply and demand sides in explaining the electoral success of radical right parties. Future studies may address this issue and include, for example, the consistency of ideological discourse and the ideological proximity of voters in explanatory models. At the same time, a more nuanced operationalization of the electoral opportunity structure may lead to different results. Instead of a dichotomous variable that accounts solely for the number of competitors, further research may distinguish between the competition of a radical right party with large electoral success and the competition of one with poor electoral success. Finally, our analysis proposes a valuable framework but with a limited scope of analysis - four countries, nine parties, and two and a half decades. This can be taken further to an extended comparative research for all radical right parties in the post-communist region or more broadly in Europe. 


\section{List of References}

Arzheimer Kai (2009): Contextual Factors and the Extreme Right Vote in Western Europe 1980-2002. In: American Journal of Political Science, vol. 53, no. 2, 259-275.

Arzheimer, Kai / Carter, Elisabeth (2006): Political Opportunity Structures and Right-Wing Extremist Party Success. In: European Journal of Political Research, vol. 45, no. 3, 419-443.

Beichelt, Timm / Minkenberg, Michael (2002): Rechtsradikalismus in Transformationsgesellschaften. Entstehungsbedingungen und Erklärungsmodel (The Radical Right in Transformation Societies. Conditions of Formation and Explanatory Model). In: Osteuropa, Vol. 52, No. 3, 247-262.

Betz, Hans-Georg (1993): The New Politics of Resentment. Radical Right-Wing Populism in Western Europe. In: Comparative Politics, Vol. 25, No. 4, 413-427.

Betz, Hans-Georg (2003): The Growing Threat of the Radical Right. In: Merkl, Peter H. / Weinberg, Leonard (eds.): Right-Wing Extremism in the Twenty-First Century. $2^{\text {nd }}$ revised edition, London: Frank Cass Publishers, 71-89.

Bíró-Nagy, András / Róna, Dániel (2013): Rational Radicalism. Jobbik's Road to the Hungarian Parliament. Unpublished manuscript.

Brichta, Avraham / Pedahzur, Ami (2002): The Institutionalization of Extreme Right-Wing Charismatic Parties: A Paradox?. In: Party Politics, Vol. 8, No. 1, 31-49.

Carter, Elisabeth (2005): The Extreme Right in Western Europe. Success or Failure?. Manchester: Manchester University Press.

De Lange, Sarah L. (2007): A New Winning Formula? The Programmatic Appeal of the Radical Right. In: Party Politics, vol. 13, no. 4, 411-435.

Eatwell, Roger (2003): Ten Theories of the Extreme Right. In: Merkl, Peter H. / Weinberg, Leonard (eds.): Right-Wing Extremism in the Twenty-First Century. $2^{\text {nd }}$ revised edition, London: Frank Cass Publishers, 45-70.

Eatwell, Roger (2004): Introduction. The New Extreme Right Challenge. In: Eatwell, Roger / Mudde, Cas (eds.): Western Democracies and the New Extreme Right Challenge. London / New York: Routledge, 1-16.

Eatwell, Roger (2005): Charisma and the Revival of the European Extreme Right. In: Rydgren, Jens (ed.): Movements of Exclusion. Radical Right-Wing Populism in the Western World. Hauppauge: Nova Science, 101-120. 
Fennema, Meindert (1997): Some Conceptual Issues and Problems in the Comparison of Anti-Immigrant Parties in Western Europe. In: Party Politics, Vol. 3, No. 4, 473-492.

Gherghina, Sergiu (2014): Party Organization and Electoral Volatility in Central and Eastern Europe. Enhancing Voter Loyalty. London: Routledge.

Ghodsee, Kristen (2008): Left Wing, Right Wing, Everything. Xenophobia, Neototalitarianism, and Populist Politics in Bulgaria. In: Problems of Post-Communism, Vol. 55, No. 3, 26-39.

Heinisch, Reinhard (2003): Success in Opposition - Failure in Government. Explaining the Performance of Right-Wing Populist Parties in Public Office. In: West European Politics, Vol. 26, No. 3, 91-130.

Ignazi, Piero (1992): The Silent Counter-Revolution. Hypotheses on the Emergence of Extreme Right-Wing Parties in Europe. In: European Journal of Political Research, Vol. $22,3-34$.

Ignazi, Piero (2003): Extreme Right Parties in Western Europe. Oxford: Oxford University Press.

Ivarsflaten, Elisabeth (2008): What Unites Right-Wing Populists in Western Europe?. ReExamining Grievance Mobilization Models in Seven Successful Cases. In: Comparative Political Studies, Vol. 41, No. 1, 3-23.

Karácsony, Gergely / Róna, Dániel (2011): The Secret of Jobbik. Reasons Behind the Rise of the Hungarian Radical Right. In: Journal of East European and Asian Studies, Vol. 2, No. 1, Special Issue: Democratic Institutionalism, 61-92.

Kitschelt, Herbert P. (1995): The Radical Right in Western Europe: A Comparative Analysis. Ann Arbor: University of Michigan Press.

Kopecký, Petr (2006): The Rise of the Power Monopoly. Political Parties in the Czech Republic. In: Jungerstam-Mulders, Susanne (ed.): Post-Communist EU Member States. Parties and Party Systems. Aldershot: Ashgate, 125-146.

Landman, Todd (2008): Issues and Methods in Comparative Politics. An Introduction. $3^{\text {rd }}$ edition, Abington / New York: Routledge.

Liang, Christina Schori (ed.) (2007): Europe for the Europeans. The Foreign and Security Policy of the Populist Radical Right. Ashgate Publishing Limited.

Lubbers, Marcel / Gijsberts, Mérove / Scheepers, Peer (2002): Extreme Right-Wing Voting in Western Europe. In: European Journal of Political Research, Vol. 41, 345-378. 
Meguid, Bonnie M. (2008): Party Competition Between Unequals: Strategies and Electoral Fortunes in Western Europe. Cambridge: Cambridge University Press

Merkl, Peter H. / Weinberg, Leonard (eds.) (2003): Right-Wing Extremism in the Twenty-First Century. $2^{\text {nd }}$ revised edition, London: Frank Cass Publishers.

Mudde, Cas (2000): The Ideology of the Extreme Right. Manchester: Manchester University Press.

Mudde, Cas (2007): Populist Radical Right Parties in Europe. Cambridge: Cambridge University Press.

Mudde, Cas (2011): Radical Right Parties in Europe. What, Who, Why?. In: Participation, Vol. 35 , No. $1,12-15$.

Mudde, Cas (2014): The Far Right and the European Elections. In: Current History, Vol. 113, No. $761,98-103$.

Norris, Pippa (2005): Radical Right. Voters and Parties in the Electoral Market. Cambridge: Cambridge University Press.

Rydgren, Jens (2005): Is Extreme Right-Wing Populism Contagious?. Explaining the Emergence of a New Party Family. In: European Journal of Political Research, Vol. 44, 413-437.

Rydgren, Jens (2007): The Sociology of the Radical Right. In: Annual Review of Sociology, Vol. 33, No. 1, 241-262.

Spies, Dennis / Franzmann, Simon T. (2011): A Two-Dimensional Approach to the Political Opportunity Structure of Extreme Right Parties in Western Europe. In: West European Politics, vol. 34, no. 5, 1044-1069.

Tarrow, Sidney (1994): Power in Movement. Social Movements and Contentious Politics. $2^{\text {nd }}$ edition, Cambridge: Cambridge University Press.

Tavits, Margit (2013): Post-Communist Democracies and Party Organization. Cambridge: Cambridge University Press.

Thieme, Tom (2007): Extremistische Parteien im Postkommunistischen Osteuropa (Extremist Parties in Post-Communist Eastern Europe). In: Aus Politik und Zeitgeschichte, Vol. 43, 21-26.

Van der Brug, Wouter / Fennema, Meindert / Tillie, Jean (2000): Anti-Immigrant Parties in Europe: Ideological or Protest Vote?. In: European Journal of Political Research, Vol. 37, No. $1,77-102$. 
Van der Brug, Wouter / Fennema, Meindert / Tillie, Jean (2005): Why Some Anti-Immigrant Parties Fail and Others Succeed. A Two-Step Model of Aggregate Electoral Support. In: Comparative Political Studies, Vol. 38, No. 5, 537-573.

Van Kessel, Stijn Theodoor (2011): Supply and Demand. Identifying Populist Parties in Europe and Explaining their Electoral Performance. Doctoral Thesis, University of Sussex.

Williams, Michelle Hale (2006): The Impact of Radical Right-Wing Parties in West European Democracies. Houndmills / New York: Palgrave Macmillan. 